ledge of those factors influencing productivity and fertility of food fishes, and the general ecology of the region. Geophysical observations will include studies of bottom topography and sedimentology together with magnetic and seismic surveys. Physical measurements, in addition to the study of particular current systems, will include the operation of additional tide gauges, radiosonde/wind stations, and synoptic observations by all survey vessels and H.M. ships in the area (The Royal Society. British National Committee for Oceanic Research. United Kingdom Scientific Programmes during the International Indian Ocean Expedition 1961-64. Pp. 22. London: The Royal Society, 1962).

\section{The Engineering Institutions Joint Council}

BritaIn's leading bodies of professional engineers, with a combined membership of more than 200,000, have set up the Engineering Institutions Joint Council under the chairmanship of Sir Kenneth Hague. The purpose of the Council is to enable representatives of the bodies concerned to meet together to consider and take action on matters of common interest relating to the advancement of engineering and the dissemination of knowledge in that field. It also aims at establishing a sound and useful channel of communication and understanding between the professional engineers, the Government, the public, and national and international bodies concerned with engineering. The bodies represented on the Council are: Royal Aeronautical Society, Institution of Chemical Engineers, Institution of Civil Engineers, Institution of Electrical Engineers, Institution of Gas Engineers, Institution of Marine Engineers, Institution of Mechanical Engineers, Institution of Mining Engineers, Institution of Mining and Metallurgy, Institution of Municipal Engineers, Institution of Production Engineers, British Institution of Radio Engineers, Institution of Structural Engineers. Mr. K. H. Platt has been appointed honorary secretary of the Council, the office of which is in the Institution of Mechanical Engineers, 1 Birdcage Walk, Westminster, S.W.1.

\section{Automatic Weather Station}

ON August 17, 1961, the world's first isotopepowered automatic weather station began transmitting weather observations to the U.S. Department of Commerce Weather Bureau from Axel Heiburg Island in Canada's Northwest Territories. Throughout its first year of operation, the unattended station has continued to report on the weather in this bleak, uninhabited region about 700 miles from the North Pole. The station was developed by the Martin Company for the United States Atomic Energy Commission and the Weather Bureau. Wind direction and speed, barometric pressure and tem. perature are continuously measured by the station's instruments. The measurements are fed into a dataprocessing system and transmitted every three hours to the Joint Canadian-United States Weather Station at Resolute, Canada. Ultimately, the Weather Bureau hopes that hundreds of these automatic stations will be placed in mountainous and polar regions, oceans and deserts, where it is impossible to establish permanent, manned weather stations.

\section{Biorheology}

AFter a new name has been coined for a new division of science it does not take long for the appropriate specialist journal to appear. The name 'rheology' was first given to the science of the deformation and flow of matter in 1929. This has covered an extremely wide field, including such diverse subjects as metals, plastics, solutions and suspensions, building materials and biological substances, in which workers may have little in common except the need for rheological techniques. As biologists have increased their interest in rheological problems, the name 'biorheology' was first used in 1948, and now a journal appears to cater for this branch of science. The reputation of its editors-inchief, Prof. A. L. Copley, of New York, and Dr. G. W. Scott Blair, of Reading, will guarantee the standing of the new journal. They are assisted by a Board of Editors from five other countries and by an Honorary Editorial Advisory Board even more widely distributed. The journal will only accept papers within the strict limits of its subject. Hydrodynamics or the classical theory of elasticity are excluded. Papers must deal with the rheology of "processes in the living organism (in vivo) and with material originating from the organism (extracorporeal)". The inter-relationship between rheological properties and structural aspects of the systems will be stressed. Papers will be in English, French and German. In addition to papers on original work (limited to 15 pages in general), there will be letters to the editor, book reviews, reports of meotings and news of interest to rheologists. The first number is well produced and clearly printed (1, No. 1; July 1962. Pp. 82. Annual subscription-rates: (A) For libraries, Government establishments, research laboratories, etc., $£ 10$ (30 dollars); $(B)$ for individuals who place their orders directly with the publisher and certify that the journal is for their personal use, £5 (15 dollars). Oxford and New York: Pergamon Press, 1962). The new venture can be warmly welcomed and confidently expected to be successful in its purpose.

\section{A Directory of British Scientists}

ERnest Benn, Ltd., who are to publish the first edition of the Directory of British Scientists in April 1963, hope to include details of some 30,000 British science graduates engaged in scientific work at the present time. This has been made possible by the co-operation of the registrars of all the British universities. While the dispatch of questionnaires to all graduates has inevitably resulted in a number of duplications, there have also been a number of forms returned owing to changes of address, etc. Any scientists who consider themselves eligible for in. clusion in the Directory (which does not cover dentistry, engineering, medicine or veterinary studies), and who have not yet received a form, are requested to write as soon as possible to: the Editorial Secretary, Directory of British Scientists, Orchard House, Caldecott Road, Abingdon, Berkshire.

\section{A Bibliography of Plastics}

A Bibltography of plastics, compiled by E. R. Yescombe, with a preface by M. Kaufman, of the National College of Rubber Technology, has been issued by the Library Association as Special Subject List No. 38 (Plastics. Pp. 40. London: Library Association, 1962. 8s.; L.A. members, 6s.). Besides a select list of periodicals, it includes some 280 entries. These are arranged under guides to the literature; abstracts and indexes; surveys and reviews; introductory - elementary treatises; generalmore advanced ; nomenclature ; trade names ; classi- 